\title{
Varjotalon ja hallin vertailu siniketun tuotantoympäristönä
}

\author{
Tapani Kivinen ${ }^{1)}$, Hannu T. Korhonen ${ }^{2)}$ \\ 1) MTT, Maatalousteknologian tutkimus, Vakolantie 55, 03400 Vihti, tapani.kivinen@mtt.fi \\ 2) MTT, Turkistutkimus, Turkistie 8, 69100 Kannus, hannu.t.korhonen@mtt.fi
}

\section{Tiivistelmä}

Turkiseläinten kasvatus on perinteisesti tapahtunut kevytrakenteisessa varjotalossa, joka nimensä mukaisesti on antanut yläpuolisen sääsuojan eläimelle ja hoitajalle. Varjotalon etuna on edullinen rakennuskustannus, mutta haittana lannan aiheuttama maaperärasitus. Minkkejä on Suomessa tarhattu hallimaisissa rakennuksissa jo muutamia vuosia, mutta kettujen kasvatuksessa halliratkaisu on uusi. Hallin vaikutuksista siniketun tarhauksessa on vain vähän kokemusta Suomen olosuhteissa. Tällä tutkimuksella pyrittiin selvittämään perinteisen varjotalon ja hallin eroja ja yhteneväisyyksiä tuotantoympäristönä.

Vertailututkimus varjotalon ja hallin välillä suoritettiin MTT:n turkistuotannon tutkimusasemalla

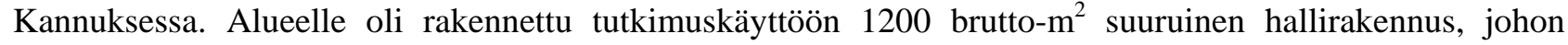
sijoitettiin 464 häkkipaikkaa. Suunnittelussa rakennukseen etsittiin uusia, aikaisemmin kokeilemattomia ratkaisuja lannanpoiston, ilmanvaihdon sekä luonnonvalon saannin suhteen. Myös häkkirakenteissa ja vedenjakelussa tehtiin uusia innovaatioita.

Koejärjestelyssä vanhoista kettuvarjotaloista yksi otettiin vertailukäyttöön. Varjotalon ja hallin välimatka toisistaan oli noin $100 \mathrm{~m}$. Kumpikin rakennus oli täynnä kettuja. Varsinainen tutkimusryhmä sisälsi siitoskaudella 50 ja kasvatuskaudella 100 sinikettua molemmissa rakennuksissa. Kumpiakin ryhmiä ruokittiin samoilla rehuilla ja molemmissa rakennuksissa tehtiin samat fysikaaliset havainnot.

Varjotalosta ja hallista mitattiin lämpötila ja suhteellinen kosteus, pölyisyys, valoisuus, ja ammoniakki. Ilman laatu arvioitiin aistinvaraisesti. Ilman liike eli tuulen nopeus mitattiin sisä- ja ulkotilasta. Ulkoilman lämpötilaa ja suhteellista kosteutta varten oli verrokkimittari läheisen huoltorakennuksen varjonpuoleisella seinällä. Lämpötila ja kosteusmittaukset kestivät kaksi vuotta ja vetoon ja valoisuuteen liittyvät mittaukset yhden vuoden. Eläimistä mitattiin keskeisimmät tuotantoon ja hyvinvointiin liittyvät parametrit kuten kasvu, rehunkulutus, lisääntyminen, nahkaominaisuudet, käyttäytyminen, stressi ja terveydentila.

Lämpötila varjotalossa oli käytännössä sama kuin ulkona yleensä. Kesän kuumina päivinä varjotalo oli hieman viileämpi. Halli oli talvella aavistuksen lämpimämpi kuin varjotalo tai ulkotila ja kesällä vain hieman viileämpi kuin ulkotila. Lämpötilaerot varjotalon ja hallin välillä olivat vain muutamia asteita ääritilanteissa. Suhteellinen kosteus käyttäytyi varjotalossa ja hallissa samalla tavalla kuin ulkona. Ilman liike oli varjotalossa vähäisempää kuin ulkotilassa ja heikkeni merkittävästi hallissa. Hallin ilmanvaihto perustui luonnollisen ilmanvaihdon periaatteeseen ja se oli herkkä tuulelle tai sen puutteelle. Ilman tulo- ja poistumisreittejä ei pystytty yksiselitteisesti selvittämään, mutta oletettavaa on, että ilma liikkui vapaasti ja ennustamattomasti kaikista käytettävissä olevista aukoista tuuliolosuhteiden mukaan. Tästä syystä pölyisyys oli suurempaa hallissa kuin varjotalossa. Ammoniakkia oli havaittavissa hallissa lähinnä lannanpoiston yhteydessä. Valoisuus alkoi lisääntyä varjotalossa noin kuukautta aikaisemmin kuin hallissa. Hallin valoisuus ohitti kuitenkin varjotalon tilanteen huhtikuun lopulla.

Eläimet kasvoivat hallissa paremmin kuin varjotalossa. Nahkaominaisuuksissa halli- ja varjotalokettujen välillä ei ollut oleellista eroa. Hallissa ketut käyttävät hyllyjä selvästi vähemmän kuin varjotalossa. Hallissa ketut ovat myös hieman passiivisempia. Muilta osin käyttäytymisessä ei ilmennyt eroja. Ketut näyttävät sopeutuvan hyvin halliolosuhteisiin. Halli on alkukeväästä pimeämpi kuin varjotalo joten ketut tulevat hieman myöhemmin kiiman. Lisääntymistulos hallissa näyttää vaihtelevan vuosittain enemmän kuin varjotalossa. Erityisesti kasvatuskaudella halli sopii hyvin siniketun tuotantoon. 


\section{Johdanto}

Turkiseläinten kasvatus on perinteisesti tapahtunut kevytrakenteisessa varjotalossa, joka nimensä mukaisesti on antanut yläpuolisen sääsuojan eläimelle ja hoitajalle. Varjotalon etuna on edullinen rakennuskustannus, mutta haittana lannan aiheuttama maaperärasitus. Minkkejä on Suomessa tarhattu hallimaisissa

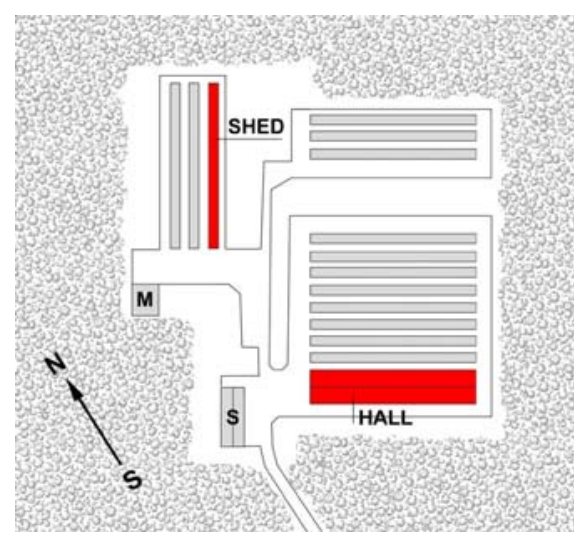

Kuva 1. koejärjestelyalueen kartta rakennuksissa jo muutamia vuosia, mutta kettujen kasvatuksessa halliratkaisu on uusi. Hallin vaikutuksista siniketun tarhauksessa on vain vähän aikaisempaa kokemusta Suomen olosuhteissa (Nydahl, ym. 1989, Pasanen 1988). Tällä tutkimuksella pyrittiin selvittämään perinteisen varjotalon ja hallin eroja tai yhteneväisyyksiä kasvatusympäristönä.

Koealueen yleisjärjestely on esitetty kuvassa $1 . \quad$ Vanhoista kettukasvatuksen varjotaloista yksi varattiin vertailurakennukseksi. Uusi kasvatushalli sijaitsee alueen eteläreunalla. Varjotalo on maantieteellisesti koillinen-lounas -suuntainen ja halli kaakko-luode suuntainen. Alueen muut rakennukset olivat huoltotila (S) ja katettu lantala (M).

\section{Aineisto}

Tutkimus kohdistui sekä rakennusten fyysisiin ominaisuuksiin (Kivinen \& Rekilä 2002) ja niistä syntyviin seuraamuksiin sinikettujen elinolosuhteissa ja miten ne edelleen heijastuvat kettujen kasvuun ja lisääntymiseen (Korhonen, ym. 2004). Aineistona oli kaksi erilaista rakennustyyppiä - varjotalo ja halli sekä 50 naarasta siitoskaudella ja 50 naarasta sekä 50 urosta kasvatuskaudella. Verrokkiryhmien lisäksi molempien rakennusten muissa häkkipaikoissa oli kettuja, jotka eivät olleet mukana itse kokeessa. Koeryhmät oli merkitty ja ryhmitelty niin, että häiriytymätön kasvutilanne oli saavutettavissa.

\section{Halli ja varjotalo}

Hallirakennus on betonianturoille perustettu puurankaseinäinen halli, jonka kattorakenteena ovat saksikattotuolit. Lattiamateriaalina on asvaltti. Lattiat on kallistettu keskeltä molempiin päihin, jossa sijaitsevat pesuvesiä varten lattiakaivot, jotka edelleen johtavat rakennusten ulkopuolella oleviin umpikaivoihin. Rakennus on eristämätön ja muistuttaa monessa suhteessa maatalouden konehallia. Hallin pohjaratkaisu on esitetty kuvassa 2. Hyötyalaa on $1175 \mathrm{~m}^{2}$ ja tilavuutta $8900 \mathrm{~m}^{3}$ Paloteknisistä ja myös toiminnallisista syistä johtuen hallista johtaa 4 poistumistietä, kaksi päädyistä ja kaksi keskialueelta molempiin suuntiin. Rehunjako- ja lannanpoistoajoneuvolla voidaan ajaa sisään molemmista päädyistä ja yhdeltä sivulta. Huoltokäytävien mitoitus perustuu optimoituun ajoneuvoleveyteen. Päädyissä ja keskialueella on sisäkääntötilaa.

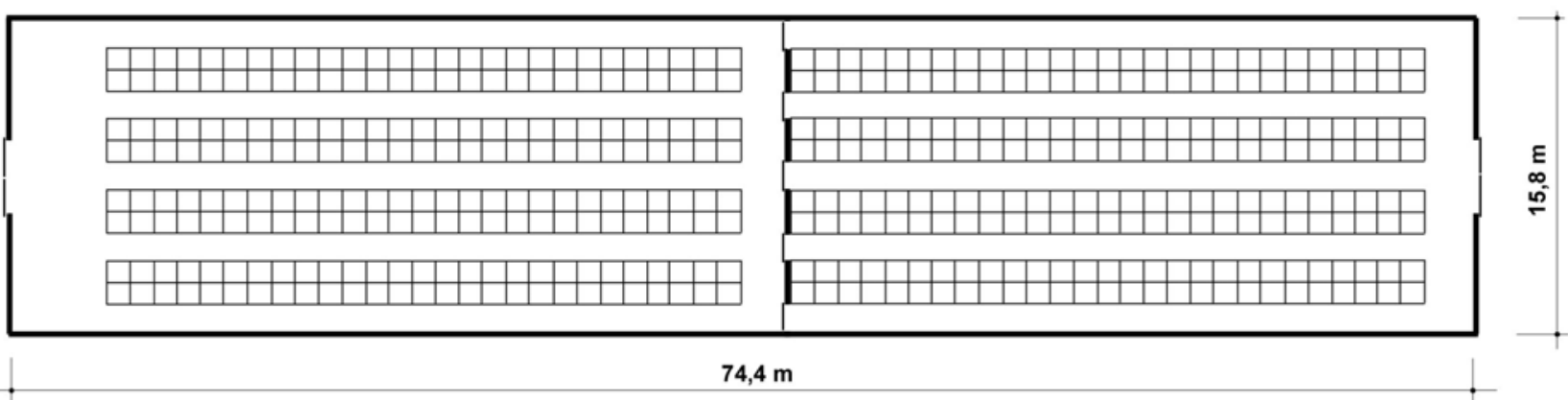

Kuva 2. Kettuhallin pohjaratkaisu on rakenteellisesti jaettu kahteen osastoon. Molemmissa osastoissa on kahdeksan häkkiriviä neljässä ryhmässä sekä viisi huoltokäytävää hoito-, ruokinta- ja lannanpoistoliikennettä varten.

Häkkien kannatus perustuu puurakenteiseen kannatinjärjestelmään, joka on tuettu vaijereilla rakennuksen ulkoseinäpilareihin ja lisäksi jäykistetty diagonaalivaijereilla. Rakenne mahdollistaa vapaan 
lannanpoistoliikenteen häkkien alla. Samalla vesilinjat sijoitettiin uudella tavalla häkkirivien väliin. Kettuhallin luonnonvalon saanti tapahtuu suurelta osin lappeissa olevista kattoikkunoista, joita on yhteensä $430 \mathrm{~m}^{2}$. Osa luonnonvalosta tulee seinän yläosassa olevista nauhaikkunoista ja seinän alaosassa sijaitsevista ilmanvaihtoaukoista. Nauhaikkunoita on $140 \mathrm{~m}^{2}$ ja iv-aukkoja $24 \mathrm{~m}^{2}$. Rakennuksen ikkuna-aukkojen pintaalan suhde lattia-alaan on siten $51 \%$, josta katon osuus $37 \%$ ja seinien osuus $14 \%$. Sähkövalon osuus on minimaalinen, hallissa on vain välttämätön työvalaistus talven pimeimpiin hetkiin ruokinta- ja hoitotilanteita varten.

Hallin rakenneratkaisu on suunniteltu niin, että koneellinen ilmanvaihto voisi tulla kyseeseen. Toimiakseen kunnolla tarvitaan sekä sisäänpuhallus- ja poistojärjestelmä. Hallin ilmanvaihto on suunniteltu ja toteutettu tapahtuvaksi luonnollisena ja painovoimaisena. Ilman sisäänotto tapahtuu molemmilta seiniltä. Nauhaikkunan yläpuolella on pysyvästi auki oleva tuloaukkovyöhyke, joka on pinta-alaltaan yhteensä $75 \mathrm{~m}^{2}$ Kesäaikaisessa ilmanvaihdossa seinien alaosien aukot avataan, jolloin tuloaukkojen määrä kasvaa 100 neliömetriin. Harjalla on jatkuva poistoaukko, jonka pinta-ala on $14 \mathrm{~m}^{2}$. Kaikissa ilman tulo- ja poistoaukoissa on lintuverkot. Kettujen tuottama lämpökuorma on minimaalinen, jolloin niistä ei juurikaan synny lämpönostetta aiheuttavaa virtausta hallin sisällä. Nosteita ja virtauksia voi ennemminkin synnyttää seinäpintojen lämpeneminen auringon säteilylämmityksen vaikutuksesta.
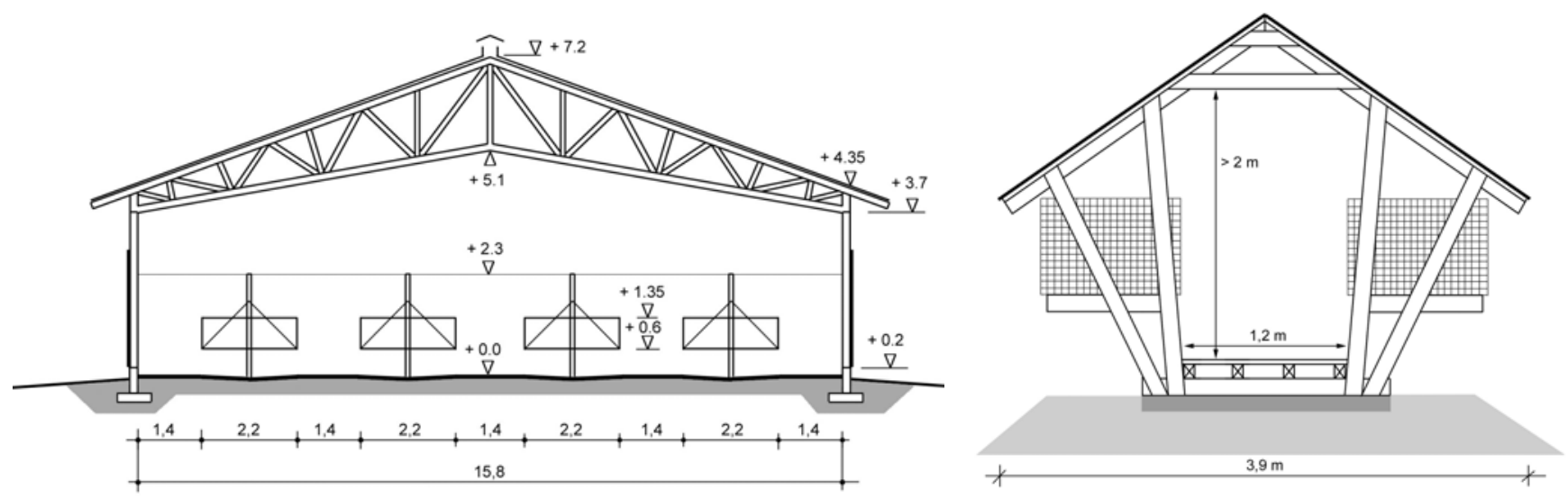

Kuva 3. Kettuhallin ja varjotalon leikkaukset, HUOM. kuvat eivät ole samassa mittakaavassa

Varjotalo on minkkien ja kettujen tarhauksessa jo useita vuosikymmeniä käytetty perinteinen rakennusratkaisu. Kannuksen kokeessa varjotalon katetun alueen leveys oli noin $4 \mathrm{~m}$ ja rakennuksen pituus $70 \mathrm{~m}$.

\section{Menetelmät ja tulokset}

\section{Ammoniakki ja pöly}

Ammoniakin määrää mitattiin dräger-putkilla syksyn 2004 ja talven 2005 aikana. Ammoniakkia ei saatu esiin varjotalossa lainkaan ja hallissa vain jonkin verran lannanpoiston yhteydessä, silloinkin alle 10 ppm.. Pölyisyyttä yritettiin aluksi mitata antureilla, mutta ne tukkeutuivat. Pölyn ja erityisesti karvojen määrää arvioitiin lopulta silmämääräisesti. Karvan määrä oli hallissa ja varjotalossa sama. Kuivikkeena käytettävän turpeen pölyäminen näkyi hallissa enemmän kuin varjotalossa tai sen lähiympäristössä.

\section{Lämpötila ja kosteus}

Lämpötilaa ja suhteellista kosteutta mitattiin Tinytag-dataloggereilla. Mittarit oli sijoitettuna eläinten häkkien tasolle, jotta tilanne kuvaisi juuri kettujen olosuhteita. Lisäksi huoltorakennuksen pohjoisseinällä oli vertailumittari. Havaintoja tehtiin kerran tunnissa.

Lämpötilojen suhteen varjotalo ja halli käyttäytyivät lähes identtisesti. Oleellisia eroja syntyi vain talven kylmimpinä ja kesän kuumimpina jaksoina. Kuvasta 4 voidaan todeta, että hallissa oli kylmimpinä jaksoina hieman lämpimämpää kuin varjotalossa tai ulkona. Pakkasen nopeassa lauhtumisessa hallin jää kylmää ilmaa ja se on vastaavasti hieman ulkotilaa kylmempi. Tilanne tasaantui heti pakkasen lähtiessä kiristymään. Kuvassa 5 kuumimpaan aikaan heinäkuussa 2005 varjotalo näyttää viileämmältä kuin halli tai ulkolämpötila. Varjotalo on nimensä mukaisesti varjotalo ja hallissa vaikuttaa kattoikkunoiden 
säteilyvaikutus, koska hallin sisä- ja ulkolämpö ovat lähes samoja. Suhteelliset kosteudet hallissa ja varjotalossa noudattivat ulkotilan lukemia, minkä perustella molempia rakennustyyppejä voidaan pitää ulkotilanomaisina.

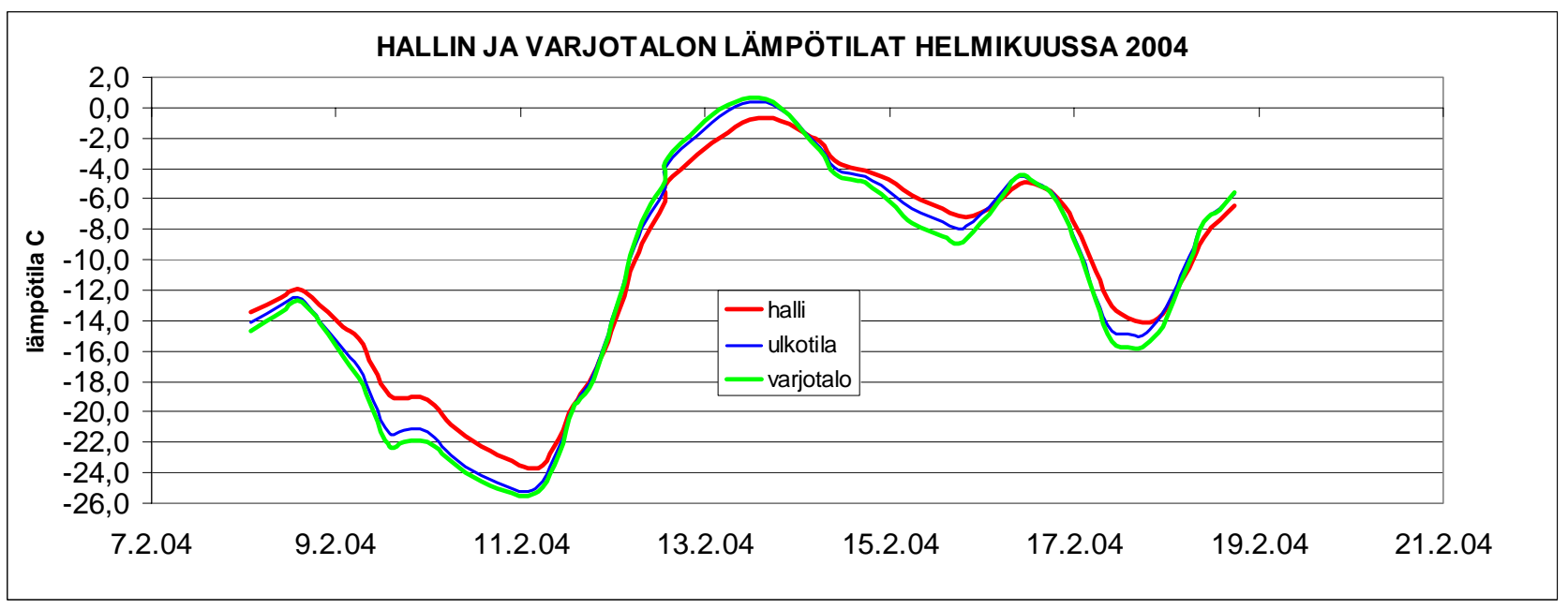

Kuva 4. Lämpötila talven kylmimpänä ajanjaksona 8. - 19.2.2004

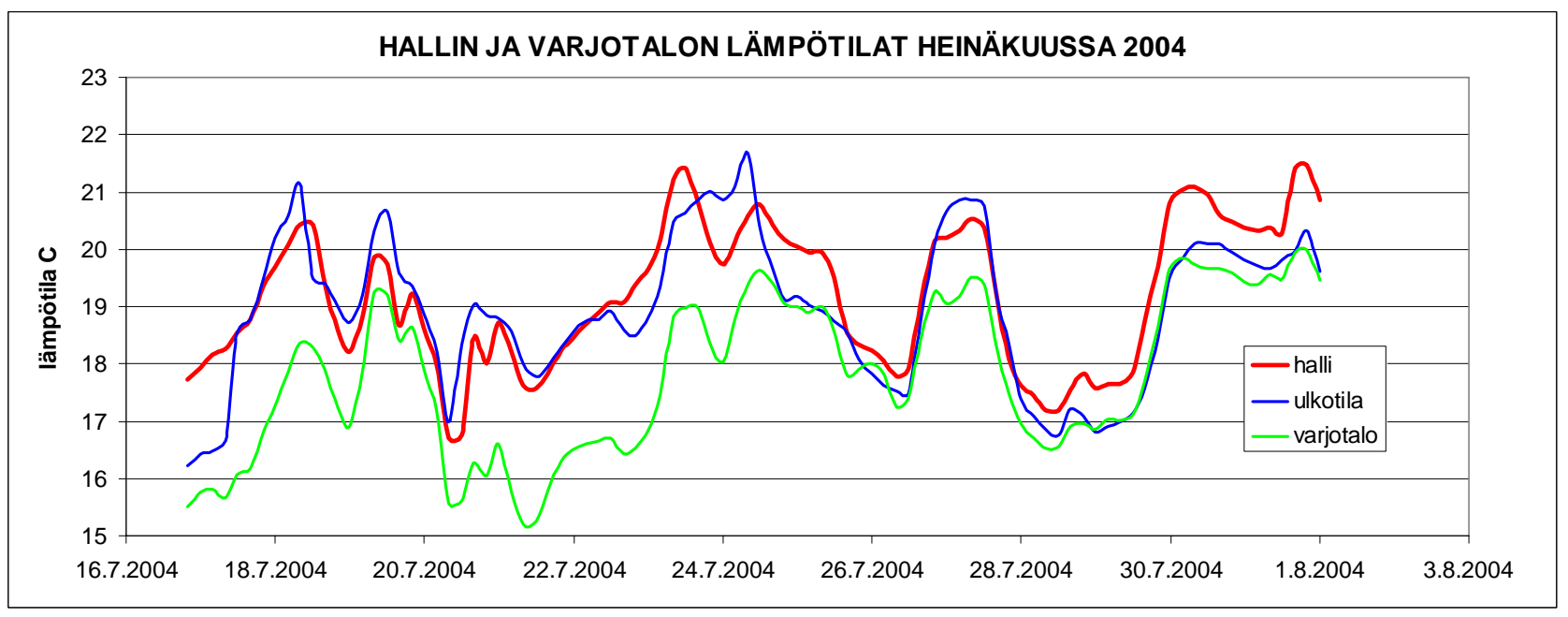

Kuva 5. Lämpötila kesän kuumimpana ajanjaksona 17.7. - 1.8.2004

\section{Valoisuusmittaukset ja niiden tulokset}

Valoisuutta mitattiin luksimittarilla kerran viikossa kolmena havaintotapahtumana aamulla, keski- ja iltapäivällä. Mittaus tehtiin juomanipan kohdalta, joka parhaiten edusti häkkiympäristöä ja siten kettujen havaintomaailmassa esiintyvää valon määrää.

Kuva 6 osoittaa valoisuuden kehittymisen. Trendiviiva osoittaa, kuinka valoisuus alkaa kasvaa ensin varjotalossa. Se selittyy varjotalon avoimilla seinillä suhteessa auringon matalaan kulmaan alkukeväästä. Auringon kulman kasvaessa hallin valoisuus ohittaa varjotalon noin kuukauden viipeellä. Tähän vaikuttivat hallin suuret kattoikkunapinnat. Tällä seikalla oli merkitystä pentutulokseen. Ketut tulivat hieman myöhemmin kiiman. Lisääntymistulos hallissa näytti vaihtelevan vuosittain enemmän kuin varjotalossa. Vuonna 2004 pentutulos hallissa oli vertailukelpoinen varjotalon kanssa. Sen sijaan vuonna 2005 pentutulos hallissa oli merkittävästi huonompi kuin varjotalossa. Pentuhävikki hallissa oli suurempi kuin varjotalossa. 


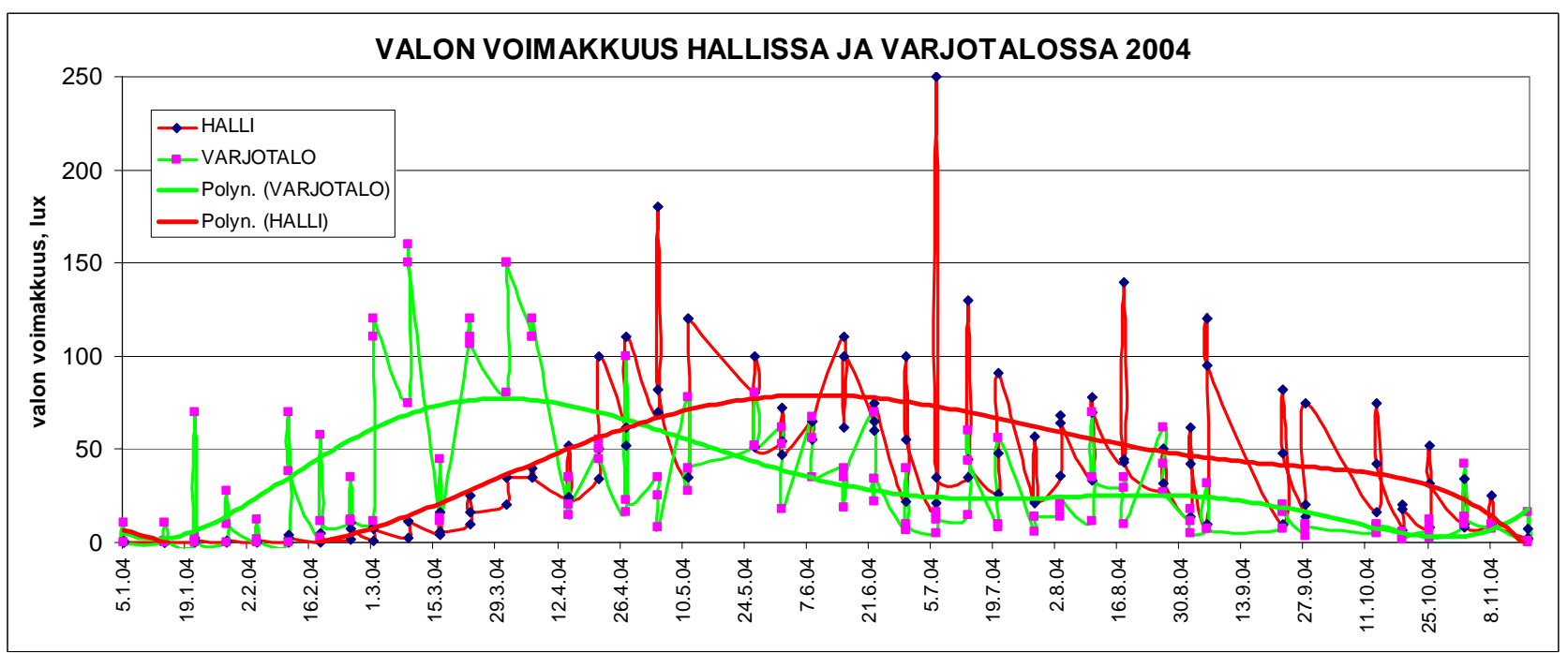

Kuva 6. Valon voimakkuuden kehitys hallissa ja varjotalossa 2004

\section{Ilman liike}

Ilman liikenopeutta mitattiin anemometrillä noin kahden viikon välein vaihtelevien tuuliolosuhteiden vallitessa. Mittaukset suoritettiin kolmena 5 kpl havainnon sarjana, joiden keskiarvot laskettiin lopullisiksi arvoiksi. Varjotaloryhmä hidastaa tuulen liikettä ja häkkitasolla ilman nopeus laskee selvästi ulkotilaan verrattuna. Hallissa ilman nopeudet laskevat selvästi varjotaloon verrattuna. Ilmanvaihdon näkökulmasta ilman pitää liikkua, ja nopeudet vaihtelivat hallin eri osissa. Lattialla nopeus oli suurempaa kuin häkkitasolla. Ilman tulo- ja poistumisreittejä ei pystytty yksiselitteisesti selvittämään, mutta oletettavaa on, että ilma liikkuu vapaasti ja ennustamattomasti kaikista käytettävissä olevista aukoista tuuliolosuhteiden mukaan. Tästä syystä pölyisyys on suurempaa hallissa kuin varjotalossa.

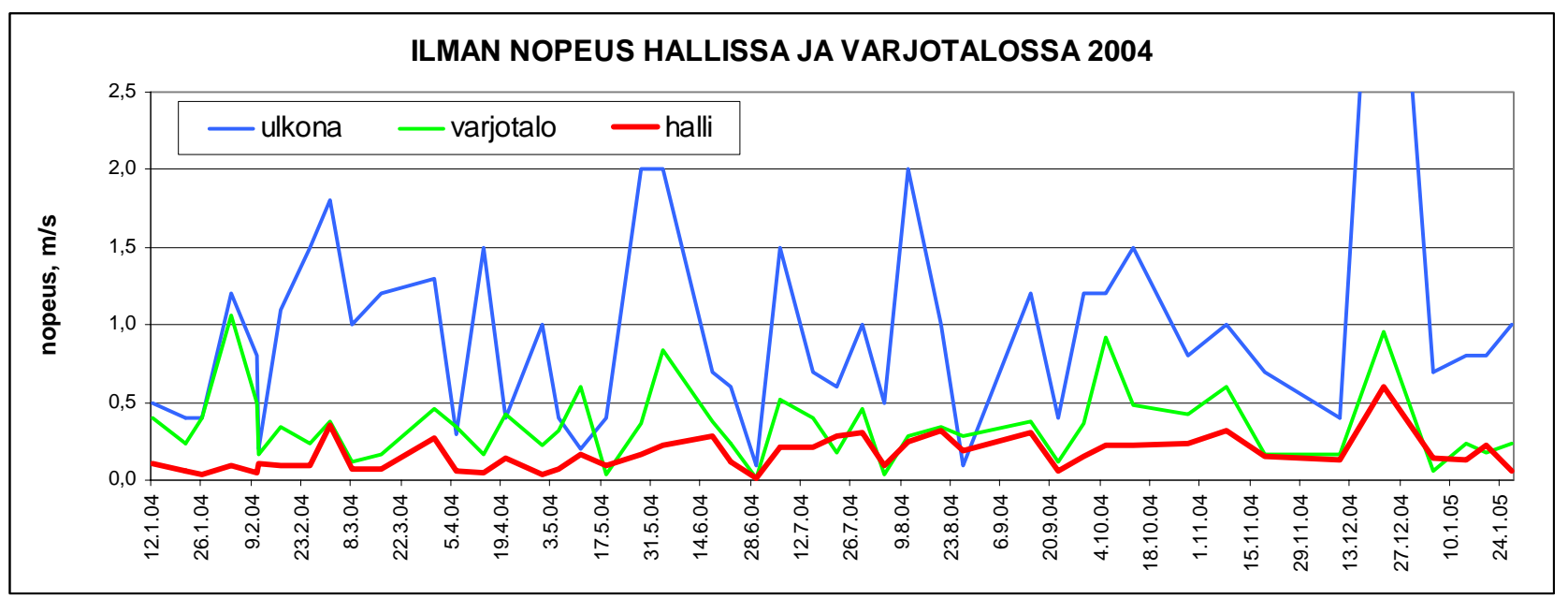

Kuva 7. Ilman nopeus hallissa, varjotalossa ja ulkona 2004.

\section{Eläinparametrit}

Eläimistä mitattiin keskeisimmät tuotantoon ja hyvinvointiin liittyvät parametrit kuten kasvu, rehunkulutus, lisääntyminen, nahkaominaisuudet, käyttäytyminen, stressi ja terveydentila. Siirto varjotalosta halliin on jonkinasteinen stressi joka näkyi alkuvaiheessa kohonneina kortisoli-kreatiiniarvoina. Myöhemmin tilanne tasaantui. Terveydentila niin hallissa kuin varjotalossakin oli hyvä.

Ketut kasvoivat hallissa paremmin kuin varjotalossa. Rehunkulutus oli sama molemmissa ryhmissä. Nahkaominaisuuksissa halli- ja varjotalokettujen välillä ei ollut oleellista eroa. Hallissa ketut käyttivät hyllyjä selvästi vähemmän kuin varjotalossa. Hallissa ketut olivat myös hieman passiivisempia. Muilta osin käyttäytymisessä ei ilmennyt eroja. Eläinten luottavaisuudessa, exploratiivisuudessa, elinten painossa (lisämunuainen, sydän, maksa, perna) ja verenkuvassa (hemoglobiini, punasolut, valkosolut, hematokriitti) ei ollut eroa halli- ja varjotalokettujen välillä. 


\section{Johtopäätökset}

Hallirakentamisen perusmotiivina oli luoda turkistarhaukseen pohjavesiä pilaamaton tiivispohjainen tuotantotila, jossa hoitajan työsuoritus voi tapahtua hallitusti sääolosuhteilta suojassa. Hallin tulee olla suunniteltu siten, että hoitokäytävillä on riittävä mitoitus ruokinta- ja lannanpoistoajoneuvoja varten. Häkkipaikan hinta on tärkeä seikka verrattaessa hallia ja varjotaloa. Varjotalo on selkeästi edullisempi, mutta ympäristönäkökulmasta vanhanaikainen ja riskialtis. Halli pitäisikin saada rakennetuksi mahdollisimman edullisesti. Kannuksen kettuhallin runko- ja vesikattorakenteet sekä verhoukset ja täydentävät rakenteet tehtiin puusta. Sen osuus hallin hinnasta oli vain $19000 €$ eli 14,5 \%. Hallirakennus maksoi $131000 €$, mikä merkitsi $111 €$ hyötyneliömetriä kohden. Hintaa voidaan pitää hyvin edullisena, kun sitä verrataan maatalouden konehallien hintoihin. Sisustus eli häkit ja juottolaitteet maksoivat $39000 €$, jolloin koko tuotantovalmis halli maksoi yhteensä $170000 €$. Häkkipaikan hinnaksi tuli siten $366 €$. Kettujen varjotalon vertailuhinta on keskimäärin $206 €$ häkkipaikkaa kohden.

Hallin käytettävyyden kannalta suuri mielenkiinto kohdistui luonnonvalon saantiin sekä ilmanvaihdon toimivuuteen syvärunkoisessa rakennuksessa. Kattoikkunoiden määrä on osoittautunut sopivaksi. Koehallin nykyinen luode-kaakko suunta ei tuottanut halliin epätasapainoista lämpötilajakaumaa eikä ilmanvaihtoa. Ilmanvaihto on riippuvainen vallitsevista tuulista, jolloin hallin sijoitus vaimentavaan puustoon nähden voi olla tärkeämpi kuin valon ja säteilyn tasapuolinen saanti pohjois-eteläsijoituksessa. Ilmanvaihto toimi siinä mielessä, että pelättyä lantakäryn kertymistä ja konsentroitumista ei ollut havaittavissa. Ilman tulo- ja menoreittejä ei pystytty identifioimaan yksiselitteisesti. Oletusarvoisesti ilma liikkui vapaasti kaikista käytettävissä olevista aukoista kulloisenkin tuulitilanteen mukaan.

Kasvatuskauden osalta tutkimustulokset ovat rohkaisevia. Eläimet kasvoivat hyvin, pysyivät terveinä ja nahkaominaisuudet olivat vertailukelpoisia varjotalo-olosuhteisiin. Eläinten siirto varjotalosta halliin näyttää olevan jonkinasteinen stressi joka näkyy pian siirron jälkeen kohonneina kortisoli-kreatiiniarvoina. Myöhemmin eläimet sopeutuivat uuteen ympäristöön hyvin.

Lisääntymiskauden 2004 osalta tulokset olivat rohkaisevia, sillä pentutulos oli hallissa yhtä hyvä kuin varjotalossakin. Molempien ryhmien naaraat olivat tosin alkujaan varjotalossa syntyneitä, mikä saattaa osaltaan vaikuttaa tulokseen. Siitoskausi 2005 oli lisääntymistulosten osalta hallissa heikko. Lopullista syytä tähän ei tiedetä. Lisääntymisen osalta lopullisten johtopäätösten tekeminen vaatii vielä jatkokokeita siitoskaudella.

\section{Kirjallisuus}

Nydahl, K. \& Fors, F. 1989. Farmteknologisk inventering. Finsk Pälstidskrift 61: 200-205.

Nydahl, K.,Fors, F. \& Lehtinen, J. 1989. Hallupfödning av pälsdjur - aktuell situation i Finland. NJF-seminarium nr 170, Stockholom 29.9.-1.10. 1980. 9 pp.

Kivinen, T. \& Rekilä, T. 2002. New structural solutions for breeding halls in Finland. NJF-seminar no. 347, Vuokatti, Finland 2-4 October, 2002. 4 pp.

Korhonen, H., Rekilä, T., Kivinen, T. \& Jauhiainen, L. 2004. Comparison of hall and shed as housing environments for blue foxes. Scientifur 28(3): 7-10.

Pasanen, S. 1988. Articop Oy:n halliratkaisut, Rääkkylä. Seminaari: Hallikasvatus ja lannanpoistomenetelmät turkistarhauksessa. Fur Center, Vantaa 3.5.1988. 3 pp. 